\title{
KEMAMPUAN SISWA DALAM MENGAITKAN OBJEK MATEMATIKA PADA SOAL POLA BILANGAN
}

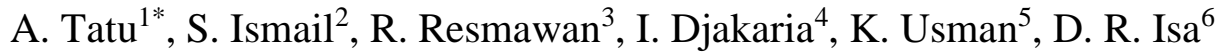 \\ 1,2,5 Program Studi Pendidikan Matematika, Universitas Negeri Gorontalo, Bone Bolango 96119, Indonesia \\ ${ }^{3}$ Program Studi Matematika, Universitas Negeri Gorontalo, Bone Bolango 96119, Indonesia \\ ${ }^{4,6}$ Program Studi Statistika, Universitas Negeri Gorontalo, Bone Bolango 96119, Indonesia \\ *Penulis Korespondensi. Email: amaliatatu1@gmail.com
}

\begin{abstract}
Abstrak
Penelitian ini dilakukan dengan tujuan untuk mengetahui sejauh mana kemampuan siswa dalam mengaitkan objek matematika pada soal-soal pola bilangan. Metode yang digunakan dalam penelitian ini adalah deskripsi kuantitaif. Teknik pengumpulan data yang digunakan adalah tes dan wawancara. Adapun teknik analisis data menggunakan model miles dan hiberman yaitu dengan mereduksi data, melakukan penyajian data dan penarikan kesimpulan. Hasil penelitian menunjukan bahwa kemampuan siswa dalam mengaitkan objek matematika pada soal pola bilangan belum maksimal. Hal ini ditunjukan dengan presentase capaian indikator kemampuan mengaitkan objek matematika yang hanya mencapai rata-rata $55,26 \%$ yang terdiri dari indikator fakta $48,44 \%$, konsep $45,50 \%$, prinsip $63,80 \%$ dan operasi $63,33 \%$.
\end{abstract}

Kata Kunci: Kemampuan Siswa; Objek Matematika; Pola Bilangan

\begin{abstract}
This research was conducted with the aim of knowing to what extent students' ability to relate mathematical objects to problems number patterns. The method used in this research is a quantitative description. The data collection techniques used are tests and interviews. The data analysis technique uses model miles and hiberman, namely by reducing data, presenting data, and drawing conclusions. The results showed that students' ability to relate mathematical objects to pattern problems numbers is not maximized. This is indicated by the percentage of achievements an indicator of the ability to associate mathematical objects that only reached an average of $55.26 \%$ consisting of $48.44 \%$ fact indicators, concept $45.50 \%$, principle $63.80 \%$, and operation $63.33 \%$.
\end{abstract}

Keywords: Student's Ability; Mathematical Object; Number Pattern

\section{Pendahuluan}

Pembelajaran matematika saat ini masih menjadi tantangan pada setiap satuan pendidikan. Pembelajara matematika mengharuskan siswa bisa memahami konsep dengan karena rendahnya pemahaman siswa terhadap konsep yang dipelajari adalah kendala dalam pembelajaran yang merupakan akibat dari kurangnya pengetahuan dan pemahaman terhadap konsep dasar materi [1]. Banyak dari kalangan siswa ataupun pelajar menganggap bahwa matematika adalah mata pelajaran yang sulit, menakutkan, menegangkan bahkan membosankan, sehingga siswa kurang aktif dalam pembelajaran. Hingga saat ini masih ada beberapa kendala yang dialami siswa dalam proses pembelajaran seperti belum mampu dalam memecahkan masalah, berpikir kritis, kurangnya kemampuan berkomunikasi dan belum mampu dalam mengaitkan objek-objek matematika. Matematika dianggap sebagai mata pelajaran yang sulit, membosankan, tidak menarik, dan bahkan cenderung dianggap sebagai momok bagi sebagian besar siswa [2]. Hal ini umumnya disebabkan karena pembelajaran matematika yang cenderung monoton, strukturalis, kurang menarik dan kurang 
kontekstual. Kesulitan siswa dalam menghadapi penyelesaian soal-soal matematika menunjukan bahwa kemampuan pemahaman konsep matematika siswa terhadap materi yang diberikan masih tergolong rendah [3]. Seseorang dikatakan memiliki kemampuan belajar apabila dalam dirinya memiliki kesanggupan atau keyakinan untuk memperoleh suatu perubahan terhadap pengetahuan. Dalam pendidikan, kemampuan siswa diasah melalui masalah, sehingga siswa mampu meningkatkan berbagai kompetensi yang dimiliknya [4].

Siswa perlu memiliki kemampuan memperoleh, memilih, dan mengolah informasi, dimana kemampuan tersebut membutuhkan kemampuan berfikir, sistematis, logis, kreatif dan kemampuan bekerja sama [5]. Dalam memecahkan masalah matematika, siswa harus memiliki kemampuan untuk mengerjakan atau menyelesaikan masalah terutama pada soal-soal pola bilangan. Materi pola bilangan sangat erat hubungannya dengan kehidupan sehari-hari dan juga terhadap objek-objek dalam matematika. Pada penelitian Nukuhaly, dkk [6] diungkapkan bahwa objek-objek matematika yang harus dikuasai siswa adalah fakta, konsep, prinsip dan operasi. Kemampuan fakta dalam matematika berkaitan dengan simbol atau lambang, konsep adalah ide dalam menggolongkan sekumpulan objek, prinsip berupa teorema atau sifat yang diketahui dalam soal dan operasi merupakan susunan dari penyelesaian soal yang berhubungan dengan penjumlahan, pengurangan, perkalian dan pembagian [7].

Dari hasil observasi didapatkan informasi bahwa objek matematika terkait dengan pola bilangan sudah dimiliki siswa, namun saat menyelesaiakan soal mereka belum menunjukan hasil yang diharapkan. Hal ini disebabkan karena masih terdapat kesalahan dalam menyelesaikan soal yang biasanya disebabkan karena siswa terburu-buru dalam menjawab. Selain itu, penyebab lain disebabkan karena siswa tidak membaca soal dengan teliti [8], dan juga tidak dapat menentukan rumus apa yang harus digunakan dalam menyelesaika masalah [9]. Pada pembelajaran pola bilangan siswa masih sulit mengerjakan soal-soal operasi hitung bilangan dan masih banyak siswa yang belum dapat menyelesaikan dengan tepat soal terkait materi tersebut. Dalam penelitian ini akan dilihat sejauh mana pengetahuan yang dimiliki siswa tentang objek matematika terkait pola bilangan melalui analisis dan deskripsi kemampuan siswa yang dilihat berdasarkan letak kemampuan siswa, dalam hal ini dengan memiliki kemampuan yang baik dalam mengaitkan objek matematika siswa diharapkan dapat menyelesaikan soal-soal pada materi pola bilangan dengan baik dan mudah untuk dikerjakan.

\section{Metode Penelitian}

Penelitian ini termasuk dalam penelitian deskripsi kuantittif, yaitu penelitian yang dimaksudkan untuk menyelidiki keadaan, kondisi atau hal lain yang sudah disebutkan, yang hasilnya dipaparkan dalam bentuk laporan penelitian [10]. Penelitian ini dilaksanakan di SMP Negeri 1 Tibawa pada kelas VIII tahun pelajaran 2020/2021. Waktu penelitian ini dilaksanakan pada bulan september sampai november 2020.

Jenis data dalam penelitian ini yaitu data primer tentang kemampuan siswa dalam mengaitkan objek matematika pada soal pola bilangan. Populasi dalam penelitian ini adalah kelas VIII SMP Negeri 1 Tibawa yang tersebar di delapan kelas. Pengambilan sampel dalam penelitian ini menggunakan teknik pengambilan sampel secara porposive sampling, dimana siswa dikelompokan berdasarkan jarak rumah terdekat sehingga diperoleh siswa berjumlah 24 sebagai subjek penelitian.

Variabel dalam penelitian ini hanya terdapat satu variabel yaitu kemampuan siswa dalam mengaitkan objek matematika pada soal pola bilangan dengan empat indikator kemampuan yaitu

1) Kemampuan fakta,

2) Kemampuan konsep,

3) Kemampuan prinsip dan

4) Kemampuan operasi.

Dalam penelitian ini teknik pengumpulan data menggunakan instrumen berupa tes essay dan wawancara. Tes essay adalah instrumen tes yang digunakan untuk mengukur sesuatu yang sifatnya penting dan pasti [11]. Adapun wawacara digunakan untuk melengkapi infomasi dari hasil 
pemberian tes. Dalam penelitian ini, tes essay digunakan untuk mengukur kemampuan siswa dalam mengaitkan objek matematika pada soal pola bilangan, sedangkan wawancara digunakan untuk memperoleh informasi tambahan tentang kemampuan siswa dalam mengaitkan objek matematika dalam soal pola bilangan. Untuk membuktikan keabsahan instrumen dalam penelitian, maka terlebih dahulu akan dilakukan uji validitas dan uji reliabilitasnya. Uji validitas menggunakan rumus korelasi produk momen dan uji reliabilitas menggunakan rumus Alfa-Cronbach. Dalam penelitian ini digunakan teknik analisis data menggunakan model Miles dan Hiberman [12] dengan tahapan-tahapan sebagai berikut:

\subsection{Reduksi Data}

Mereduksi data berarti merangkum, memilih hal-hal pokok, memfokuskan pada hal-hal yang penting, dicari tema dan polanya. Dalam mereduksi data, peneliti akan memfokuskan pada kemampuan siswa dalam mengaitkan objek matematika dalam soal pola bilangan. Dalam mereduksi data, tahapan yang akan dilakukan adalah seagai berikut:

a. Memeriksa dan menganalisis hasil kerja siswa pada tes tertulis yag telah diberikan dengan melihat sejauh mana kemampuan siswa dalam mengaitkan objek matematika yaitu fakta, konsep, operasi dan prinsip.

b. Mencatat hasil wawancara dengan siswa untuk memperoleh informasi yang dibutuhkan mengenai hasil dari tes yang sudah dilakukan dengan melihat indikator yang berhubungan dengan fakta, konsep, operasai dan prinsip.

c. Menganalisis data yang sudah diperoleh sesuai dengan informasi yang diperlukan dalam penelitian, yang dalam hal ini mengenai kemampuan siswa dalam mengatkan objek matematika.

\subsection{Penyajian Data}

Setelah melakukan reduksi data, langkah selanjutnya yaitu proses penyajian data. Dalam hal ini data disajikan sesuai dengan keperluan yang akan diteliti mengenai data kemampuan siswa dalam mengaitkan objek matematika yang diperoleh dari hasil kerja siswa dan juga wawancara. Penyajian data dilakukan dalam bentuk deskriptif, selanjunya dianalisis menggunakan analisis presentase. Analisis presentase dilakukan pada masing-masing soal dan indikator kemampuan dalam mengaitkan objek matematika. Untuk mengetahui presentase indikator kemampuan dalam mengaitksn objek matematika dilakukan perhitungan dengan rumus sebagai berikut:

$$
\text { Kemampuan Siswa }=\frac{\text { Jumlah Skor yang Diperoleh }}{\text { Jumlah Skor Maksimal }} \times 100 \% \text {. }
$$

Selanjutnya akan akan ditentukan nilai siswa berdasarkan kriteria kemampuan yang terdiri atas kelompok siswa berkemampuan tinggi, kelompok siswa berkempuan sedang dan kelompok siswa berkemampuan rendah.

Pengelompokan siswa tersebut menggunakan kriteria sebagai berikut [13]:

a. Kelompok dengan kemampuan tinggi

$$
\text { Hasil Tes } \geq \bar{x}+S D
$$

b. Kelompok dengan kemampuan sedang

$$
\bar{x}-S D \leq \text { Hasil Tes }<\bar{x}+S D
$$

c. Kelompok dengan kemampuan rendah 


\section{Hasil Tes $<\bar{x}-S D$}

\subsection{Penarikan Kesimpulan/Verivikasi}

Setelah dilakukan penyajian data, selanjutnya adalah penarikan kesimpulan atau verivikasi data. data yang sudah diperoleh kemudian akan disimpulkan sesuai dengan tujuan penelitian tentang kemampuan siswa dalam penelitian.

\section{Hasil dan Pembahasan}

Penelitian ini dilakukan untuk mengetahui kemampuan siswa dalam mengaitkan objek matematika pada materi pola bilangan yang dilihat berdasarkan data hasil tes kemampuan objek matematika serta data hasil wawancara dari siswa itu sendiri.

Berdasarkan data hasil tes kemampuan siswa berdasarkan kriteria diperoleh jumlah siswa pada tingkat kemampuan tinggi sebanyak 7 orang, kemampuan sedang 11 orang dan kemampuan rendah 6 orang. Hasil tes pada kelompok kemampuan siswa diuraikan berdasarkan perolehan pada masing-masing nomor soal dan berdasarkan indikator kemampuan mengaitkan objek matematika.

\subsection{Deskripsi Hasil Penelitian Berdasarkan Nomor Soal}

Deskripsi hasil penelitian berdasarakan nomor soal dilakukan untuk mendeskripsikan atau menggambarkan kemampuan siswa dalam mengaitkan objek matematika pada materi pola bilangan dengan dideskripsikan berdasarkan kategori kemampuan siswa yang berkemampuan tinggi, sedang dan rendah.

\section{a. Siswa Berkemampuan Tinggi \\ 1) Soal Nomor Satu}

Pada soal nomor satu, dari ketujuh siswa berkemampuan tinggi terdapat 6 orang atau sekitar $86 \%$ berhasil mengaitkan fakta dan konsep, dan $100 \%$ siswa berhasil mengaitkan indikator prinsip dan operasi.

\section{2) Soal Nomor Dua}

Pada soal nomor dua, dari ketujuh siswa berkemampuan tinggi 100\% siswa dapat mengaitkan fakta, sementara terdapat 6 orang atau sekitar $86 \%$ berhasil mengaitkan indikator konsep, prinsip dan operasi.

\section{3) Soal Nomor Tiga}

Pada soal nomor tiga, dari ketujuh orang siswa tersebut yang berhasil mengaitkan fakta dalam penyelesaian ini sebanyak 5 orang siswa atau sekitar 71,42\%, konsep sebanyak 2 orang siswa atau sekitar $29 \%$, prinsip sebanyak 4 orang atau sekitar $57,10 \%$ dan yang berhasil mengaitkan operasi sebanyak 6 orang atau sekitar $86 \%$.

\section{4) Soal Nomor Empat}

Pada soal nomor empat, dari ketujuh orang siswa tersebut yang berhasil mengaitkan fakta dalam penyelesaian ini sebanyak 5 orang siswa atau sekitar 71,42\%, konsep sebanyak 3 orang siswa atau sekitar $43 \%$, prinsip sebanyak 5 orang atau sekitar $71,42 \%$ dan yang berhasil mengaitkan operasi sebanyak 6 orang atau sekitar $86 \%$.

\section{5) Soal Nomor Lima}

Pada soal nomor lima, dari ketujuh orang siswa tersebut yang berhasil mengaitkan fakta dalam penyelesaian ini sebanyak 2 orang siswa atau sekitar 29\%, konsep sebanyak 4 orang siswa 
atau sekitar $57,1 \%$, prinsip sebanyak 5 orang atau sekitar $71,42 \%$ dan yang berhasil mengaitkan operasi sebanyak 6 orang atau sekitar $86 \%$.

\section{6) Soal Nomor Enam}

Pada soal nomor enam, dari ketujuh siswa berkemampuan tinggi terdapat 6 orang atau sekitar $86 \%$ berhasil mengaitkan fakta dan konsep, sementara indikator $100 \%$ siswa berhasil mengaitkan indikator prinsip dan operasi.

\section{7) Soal Nomor Tujuh}

Pada soal nomor tujuh, dari ketujuh orang siswa tersebut yang berhasil mengaitkan fakta dalam penyelesaian ini sebanyak 4 orang siswa atau sekitar 14,28\%, konsep sebanyak 4 orang siswa atau sekitar 14,28\%, prinsip sebanyak 3 orang atau sekitar $43 \%$ dan yang berhasil mengaitkan operasi sebanyak 2 orang atau sekitar $29 \%$.

\section{8) Soal Nomor Delapan}

Pada soal nomor delapan, dari ketujuh orang siswa tersebut yang berhasil mengaitkan fakta dalam penyelesaian ini sebanyak 5 orang siswa atau sekitar 71,42\%, konsep sebanyak 3 orang siswa atau sekitar $43 \%$, prinsip sebanyak 5 orang atau sekitar $71,42 \%$ dan yang berhasil mengaitkan operasi sebanyak 3 orang atau sekitar $43 \%$.

\section{b. Siswa Berkemampuan Sedang}

1) Soal Nomor Satu

Pada soal nomor satu, dari kesebelas orang siswa tersebut yang berhasil mengaitkan fakta dalam penyelesaian ini sebanyak 5 orang siswa atau sekitar 45,45\%, konsep sebanyak 3 orang siswa atau sekitar 27,27\%, sementara sebanyak 6 orang siswa atau 55\% berhasil mengaitkan indikator prinsip dan operasi.

\section{2) Soal Nomor Dua}

Pada soal nomor dua, dari kesebelas orang siswa tersebut yang berhasil mengaitkan fakta dalam penyelesaian ini sebanyak 5 orang siswa atau sekitar $45,45 \%$, sebanyak 4 orang siswa atau sekitar 36,36\% berhasil mengaitkan konsep dan prinsip dan yang berhasil mengaitkan operasi sebanyak 5 orang atau sekitar $45,45 \%$.

\section{3) Soal Nomor Tiga}

Pada soal nomor tiga, dari kesebelas orang siswa tersebut yang berhasil mengaitkan fakta dalam penyelesaian ini sebanyak 7 orang siswa atau sekitar 64\%, konsep sebanyak 3 orang siswa atau sekitar $27,27 \%$, prinsip sebanyak 4 orang atau sekitar $36,36 \%$ dan yang berhasil mengaitkan operasi sebanyak 5 orang atau sekitar $45,45 \%$.

\section{4) Soal Nomor Empat}

Pada soal nomor empat, dari kesebelas orang siswa tersebut yang berhasil mengaitkan fakta dalam penyelesaian ini sebanyak 1 orang siswa atau sekitar 9,09\%, konsep sebanyak 3 orang siswa atau sekitar $27,27 \%$, prinsip sebanyak 8 orang atau sekitar $73 \%$ dan yang berhasil mengaitkan operasi sebanyak 7 orang atau sekitar $64 \%$.

\section{5) Soal Nomor Lima}

Pada soal nomor lima, dari kesebelas orang siswa tersebut yang berhasil mengaitkan fakta dalam penyelesaian ini sebanyak 2 orang siswa atau sekitar 18,18\%, untuk mengaitkan konsep 
tidak ada siswa yang berhasil memperoleh nilai maksimum, prinsip sebanyak 6 orang atau sekitar $55 \%$ dan yang berhasil mengaitkan operasi sebanyak 2 orang atau sekitar 18,18\%.

\section{6) Soal Nomor Enam}

Pada soal nomor enam, dari kesebelas orang siswa tersebut yang berhasil mengaitkan fakta dalam penyelesaian ini sebanyak 9 orang siswa atau sekitar $82 \%$, konsep sebanyak 4 orang siswa atau sekitar $36,36 \%$, prinsip sebanyak 5 orang atau sekitar $45,45 \%$ dan yang berhasil mengaitkan operasi sebanyak 4 orang atau sekitar $36,36 \%$.

\section{7) Soal Nomor Tujuh}

Pada soal nomor tujuh, dari kesebelas orang siswa tersebut yang berhasil mengaitkan fakta dalam penyelesaian ini sebanyak 2 orang siswa atau sekitar $18,18 \%$, konsep sebanyak 2 orang siswa atau sekitar $18,18 \%$, prinsip sebanyak 7 orang atau sekitar $64 \%$ dan yang berhasil mengaitkan operasi sebanyak 2 orang atau sekitar $18,18 \%$.

\section{8) Soal Nomor Delapan}

Pada soal nomor delapan, dari kesebelas orang siswa tersebut yang berhasil mengaitkan fakta dalam penyelesaian ini sebanyak 4 orang siswa atau sekitar $36,36 \%$, untuk mengaitkan konsep tidak ada siswa yang berhasil memperoleh nilai maksimum, prinsip sebanyak 3 orang atau sekitar $27,27 \%$ dan yang berhasil mengaitkan operasi sebanyak 2 orang atau sekitar 18,18\%.

\section{c. Siswa Berkemampuan Rendah}

1) Soal Nomor Satu

Pada soal nomor satu, dari keenam orang siswa tersebut yang berhasil mengaitkan fakta dalam penyelesaian ini sebanyak 1 orang siswa atau sekitar $17 \%$, untuk mengaitkan konsep tidak ada siswa yang berhasil memperoleh nilai maksimum, sementara sekitar 2 orang atau 33,33\% dan yang berhasil mengaitkan prinsip dan operasi.

\section{2) Soal Nomor Dua}

Pada soal nomor dua, dari keenam orang siswa tersebut tidak ada yang berhasil mengaitkan fakta atau memperoleh nilai maksimum, siswa yang berhasil mengaitkan konsep sebanyak 2 orang siswa atau sekitar $33,33 \%$, prinsip sebanyak 4 orang atau sekitar $67 \%$ dan yang berhasil mengaitkan operasi sebanyak 3 orang atau sekitar $50 \%$.

\section{3) Soal Nomor Tiga}

Pada soal nomor tiga, dari keenam orang siswa tersebut yang berhasil mengaitkan fakta dalam penyelesaian ini sebanyak 2 orang siswa atau sekitar 33,33 \%, untuk indikator kemampuan konsep, prinsip dan operasi dari keenam siswa tersebut semuanya belum berhasil mengatikan objek matematika secara maksimal.

\section{4) Soal Nomor Empat}

Pada soal nomor empat, dari keenam orang siswa tersebut belum ada yang berhasil mengaitkan fakta dan konsep atau memperoleh nilai maksimum, prinsip sebanyak 1 orang atau sekitar $17 \%$ dan yang berhasil mengaitkan operasi sebanyak 4 orang atau sekitar $67 \%$.

\section{5) Soal Nomor Lima}

Pada soal nomor lima, dari ketujuh orang siswa tersebut belum ada yang berhasil mengaitkan objek matematika fakta, konsep, prinsip dan operasi secara maksimal. 


\section{6) Soal Nomor Enam}

Pada soal nomor enam, dari keenam orang siswa tersebut tidak ada yang berhasil mengaitkan fakta dalam penyelesaian ini, siswa yang berhasil mengaitkan konsep dari penyelesaian ini sebanyak 1 orang siswa atau sekitar 17\%, prinsip sebanyak 2 orang atau sekitar 33,33\% dan yang berhasil mengaitkan operasi sebanyak 1 orang atau sekitar $17 \%$.

\section{7) Soal Nomor Tujuh}

Pada soal nomor tujuh, dari keenam orang siswa tersebut tidak ada yang berhasil mengaitkan kemampuan fakta, konsep dan operasi secara maksimal. Siswa yang berhasil mengaitkan prinsip dari penyelesaian ini sebanyak 1 orang atau sekitar $17 \%$.

\section{8) Soal Nomor Delapan}

Pada soal nomor delapan dari keenam orang siswa tersebut yang berhasil mengaitkan fakta dalam penyelesaian ini sebanyak 2 orang siswa atau sekitar 33,33\%, untuk indikator kemampuan konsep, prinsip dan operasi dari keenam siswa tersebut semuanya belum berhasil mengatikan objek matematika secara maksimal.

\subsection{Deskripsi Kemampuan Siswa Berdasarkan Indikator}

Deskripsi hasil penelitian berdasarakan indikator dilakukan untuk mendeskripsikan atau menggambarkan kemampuan siswa dalam mengaitkan objek matematika pada materi pola bilangan dengan dideskripsikan berdasarkan indikator kemampuan fakta, konsep, prinsip dan operasi pada masing-masing kriteria kelompok siswa berkemampuan tinggi, sedang dan rendah.

\section{a. Indikator Kemampuan Fakta}

Pada indikator kemampuan fakta sebagian siswa sudah mampu menuliskan lambang-lambang atau simbol huruf dan kata pada soal matematika dalam materi pola bilangan. Contohnya siswa menuliskan dalam diketahui dan ditanyakan dalam soal menggunakan simbol a sebagai suku pertama dari susunan bilangan atau simbol b yang merupakan beda atau selisih dalam pola bilangan. Skor maksimal dalam indikator kemampuan fakta adalah 32 sehingga capaian kemampuan siswa dari masing-masing kelompok pada indikator fakta adalah sebagai berikut:

1) Siswa Berkemampuan Tinggi

Total skor maksimal adalah 32 × $7=224$. Siswa kelompok ini memperoleh skor 166 .

$$
\frac{166}{224} \times 100 \%=74,10 \%
$$

2) Siswa Berkemampuan Sedang

Total skor maksimal adalah 32 x $11=352$. Siswa dalam kelompok ini memperoleh skor 185 .

$$
\frac{185}{352} \times 100 \%=53 \%
$$

3) Siswa Berkemampuan Rendah

Total skor maksimal adalah 32 × $6=192$. Siswa dalam kelompok ini memperoleh skor 35 . 


$$
\frac{35}{192} \times 100 \%=18,22 \%
$$

Dari ketiga presentase kemampuan siswa pada masing-masing kelompok siswa berkemampua tinggi, sedang dan rendah diperoleh rata-rata presentase pada tahap indikator kemampuan fakta sebesar $48,44 \%$.

\section{b. Indikator Kemampuan Konsep}

Pada indikator kemampuan konsep beberapa siswa sudah memahami konsep dalam membedakan operasi hitung serta menggolongkan jenis-jenis pola bilangan dan sebagian lagi belum mampu dalam membedakan operasi hitung dan juga jenis-jenis pola bilangan. Skor maksimal dalam indikator kemampuan konsep adalah 32 sehingga capaian kemampuan siswa dari masing-masing kelompok pada indikator konsep adalah sebagai berikut:

1) Siswa Berkemampuan Tinggi

Total skor maksimal adalah 32 × $7=224$. Siswa dalam kelompok ini memperoleh skor 172 .

$$
\frac{172}{224} \times 100 \%=77 \%
$$

2) Siswa Berkemampuan Sedang

Total skor maksimal adalah 32 x $11=352$ Siswa dalam kelompok ini memperoleh skor 146 .

$$
\frac{146}{352} \times 100 \%=41,47 \%
$$

3) Siswa Berkemampuan Rendah

Total skor maksimal adalah 32 x $6=192$. Siswa dalam kelompok ini memperoleh skor 34 .

$$
\frac{34}{192} \times 100 \%=18 \%
$$

Dari ketiga presentase kemampuan siswa pada masing-masing kelompok siswa berkemampua tinggi, sedang dan rendah diperoleh rata-rata presentase pada tahap indikator kemampuan konsep sebesar $45,50 \%$.

\section{c. Indikator Kemampuan Prinsip}

Pada indikator kemampuan prinsip siswa sudah mampu menuliskan rumus dalam menjawab soal pada materi pola bilangan untuk menyelesaikan soal yang diberikan. Skor maksimal dalam indikator kemampuan prinsip adalah 32 sehingga capaian kemampuan siswa dari masing-masing kelompok pada indikator prinsip adalah sebagai berikut:

1) Siswa Berkemampuan Tinggi

Total skor maksimal adalah 32 x $7=224$. Siswa dalam kelompok sini memperoleh skor 202 .

$$
\frac{202}{224} \times 100 \%=90,17 \%
$$


2) Siswa Berkemampuan Sedang

Total maksimal adalah 32 x $11=352$. Siswa dalam kelompok ini memperoleh skor 219 .

$$
\frac{219}{352} \times 100 \%=62,21 \%
$$

3) Siswa Berkemampuan Rendah

Total skor maksimal adalah 32 × $6=192$. Siswa dalam kelompok ini memperoleh skor 74 .

$$
\frac{74}{192} \times 100 \%=39 \%
$$

Dari ketiga presentase kemampuan siswa pada masing-masing kelompok siswa berkemampuan tinggi, sedang dan rendah diperoleh rata-rata presentase pada tahap indikator kemampuan prinsip sebesar $63,80 \%$.

\section{d. Indikator Kemampuan Operasi}

Pada indikator kemampuan operasi siswa sudah dapat melakukan perhitungan dan membuat langkah kerja dalam menyelesaikan soal meski ada beberapa siswa yang belum mampu untuk melakukan perhitungan serta membuat langkah kerja dalam penyelesian soal. Skor maksimal dalam indikator kemampuan operasi adalah 32 sehingga capaian kemampuan siswa dari masing-masing kelompok pada indikator operasi adalah sebagai berikut:

1) Siswa Berkemampuan Tinggi

Total skor maksimal adalah 32 x $7=224$. Siswa dalam kelompok ini memperoleh skor 201 .

$$
\frac{201}{224} \times 100 \%=90 \%
$$

2) Siswa Berkemampuan Sedang

Total skor maksimal adalah 32 x $11=352$. Siswa dalam kelompok ini memperoleh skor 220 .

$$
\frac{220}{352} \times 100 \%=63 \%
$$

3) Siswa Berkemampuan Rendah

Total skor maksimal adalah 32 x $6=192$. Siswa dalam kelompok ini memperoleh skor 71 .

$$
\frac{71}{192} \times 100 \%=37 \%
$$

Dari ketiga presentase kemampuan siswa pada masing-masing kelompok siswa berkemampua tinggi, sedang dan rendah diperoleh rata-rata presentase pada tahap indikator kemampuan operasi sebesar $63,33 \%$.

Siswa memiliki kemampuan yang maksimal dalam mengaitkan objek matematika apabila siswa mampu mengaitkan fakta, konsep, prinsip dan operasi dalam menyelesaikan suatu masalah. Misalkan perhatikan soal nomor satu sebagai berikut: 


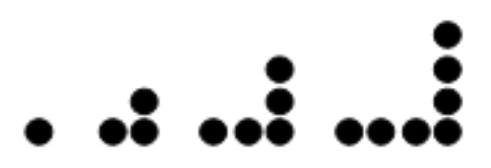

Tentukan jenis pola bilangan yang terbentuk dan berapa banyak susunan lingkaran yang dibutuhkan pada pola ke-11?

Pada soal ini yang ditanyakan atau yang harus dijawab oleh siswa adalah menetukan suku ke11 dari pola bilangan ganjil. Dalam menetukan suku ke-11, siswa harus memiliki kemampuan objek matematika. Objek matematika fakta didalam soal tersebut adalah "pola barisan bilangan = 1, 3, 5, 7 , ..." objek konsep dalam soal tersebut adalah siswa harus bisa membedakan jenis-jenis pola bilangan, ketika siswa sudah bisa membedakan jenis pola bilangan pada soal tersebut maka selanjutnya objek matematika yang digunakan adalah prinsip yang wujudnya adalah rumus untuk menetukan suku ke-11 dari pola bilangan ganjil. Rumus yang digunakan pada soal tersebut adalah $U_{n}=2 n-1$. Selanjutnya siswa akan melakukan operasi sesuai dengan prinsip $U_{n}=2 n-1$, dalam hal ini siswa harus menujukan kemampuan yang tepat atau maksimal dalam menjawab soal tersebut menggunakan prinsip yang ditunjukan oleh rumus $U_{n}=2 n-1$ dan siswa harus menghitung menggunakan operasi yang ada didalamnya. Operasi yang ada dalam soal tersebut adalah operasi perkalian dan operasi pengurangan. Dalam rumus tersebut siswa harus mendahulukan operasi perkalian kemudian operasi pengurangan untuk mendapatkan hasil yang maksimal dalam penyelesain soal.

Dari data hasil penelitian yang diperoleh untuk masing-masing soal-soal, kemampuan siswa dalam mengaitkan objek matematika fakta, konsep, prinsip dan operasi belum maksimal kemampuannya seperti yang ditunjukan oleh data yang diuraikan pada hasil peneltian.

\section{Kesimpulan}

Kemampuan siswa dalam mengaitkan objek matematika dalam menjawab soal pola bilangan masih tergolong rendah dan belum mencapai nilai maksimal. Hal ini ditunjukan dengan presentase capaian indikator kemampuan mengaitkan objek matematika yang hanya mencapai rata-rata $55,26 \%$, yang terdiri dari indikator kemampuan fakta 48,44\%, indikator kemampuan konsep $45,49 \%$, indikator kemampuan prinsip 63,80\% dan indikator kemampuan operasi $63,33 \%$.

\section{Referensi}

[1] A. Andar and I. Ikman, "Deskripsi Kesalahan Siswa dalam Menyelesaika Soal-soal Ujian Semester Matematika Siswa Kelas VIII SMP Negeri 10 Kendari," J. Penelit. Pendidik. Mat., vol. 4, no. 2, pp. 15-28, 2016.

[2] T. G. Ratumanan and T. Laurens, "Analisis Penguasaan Objek Matematika (Kajian pada Lulusan SMA Di Provinsi Maluku),” J. Pendidik. Mat. Raflesia, vol. 1, no. 2, pp. 146-154, 2016, doi: https://doi.org/10.31186/jpmr.v1i2.4005.

[3] L. Yulianah, K. Ni'mah, and D. V. Rahayu, "Analisis Kemampuan Pemahaman Konsep Matematika Siswa Berbantuan Media Schoology," J. Deriv. J. Mat. dan Pendidik. Mat., vol. 7, no. 1, pp. 39-45, Jul. 2020, doi: 10.31316/j.derivat.v7i1.863.

[4] T. S. Sumartini, "Peningkatan Kemampuan Pemecahan Masalah Matematis Siswa melalui Pembelajaran Berbasis Masalah," Mosharafa J. Pendidik. Mat., vol. 5, no. 2, pp. 148-158, Aug. 2018, doi: 10.31980/mosharafa.v5i2.270.

[5] R. Fuadi, R. Johar, and S. Munzir, "Meningkatkan Kemampuan Pemahaman dan Penalaran Matematika Melalui pendekatan Kontekstual," J. Didakt. Mat., vol. 7, no. 1, pp. 47-54, 2016. 
[6] N. A. Nukuhaly, G. Assagaf, and J. Muhamad, "Analisis Kesalahan dalam Menyelesaikan Soal-soal Pola Bilangan Pada Siswa Kelas VIII SMP Negeri 14 Ambon," in Prosiding SEMNAS Matematika \& Pendidikan Matematika IAIN Ambon, 2018, pp. 103-111.

[7] W. Herdiana, "Analisis Kesalahan Menyelesaikan Soal Pola Bilangan Pada Siswa Kelas VIII SMP Pesantren Gupi Semata Kabupaten Gowa," Universitas Muhammadiyah Makasar, 2019.

[8] S. R. Fitriatien, "Analisis Kesalahan dalam Menyelesaikan Soal Cerita Matematika Berdasarkan Newman," JIPMat, vol. 4, no. 1, pp. 53-64, Apr. 2019, doi: 10.26877/jipmat.v4i1.3550.

[9] N. Farida, “Analisis Kesalahan Siswa SMP Kelas VIII dalam Menyelesaikan Masalah Soal Cerita Matematika," AKSIOMA J. Math. Educ., vol. 4, no. 2, pp. 42-52, Dec. 2015, doi: 10.24127/ajpm.v4i2.306.

[10] S. Arikunto, Prosedur Penelitian Suatu Pendeaktan Praktik. Jakarta: Rineka Cipta, 2015.

[11] S. Arikunto, Manajemen Penelitian. Jakarta: Rineka Cipta, 2010.

[12] S. Sugiono, Metode Penelitian Pendidikan. Bandung: Alfabeta, 2016.

[13] T. Machmud, "Peningkatan Kemampuan Komunikasi Pemecahan Masalah Matematis dan Self-Efficacy Siswa SMP Melalui Pendekatan Problem-Centered Learning dengan Strategi Scoffoalding," Universitas Pendidikan Indonesia, 2013. 